\title{
DROPLETS FROM THE PLANKTON NET -XX. "SEA STINGS" CAUSED BY CRESEIS ACICULA RANG (MOLLUSCA : PTEROPODA) IN JAPAN-
}

\author{
$\operatorname{AUTHOR}(\mathrm{S})$ :
}

Nishimura, Saburo

\section{CITATION:}

Nishimura, Saburo. DROPLETS FROM THE PLANKTON NET -XX. "SEA STINGS" CAUSED BY CRESEIS ACICULA RANG (MOLLUSCA: PTEROPODA) IN JAPAN-. PUBLICATIONS OF THE SETO MARINE BIOLOGICAL LABORATORY 1965, 13(4):287-290

\section{ISSUE DATE:}

1965-12-15

URL:

http://hdl.handle.net/2433/175411

RIGHT: 


\section{DROPLETS FROM THE PLANKTON NET \\ XX. "SEA STINGS" CAUSED BY CRESEIS ACICULA RANG (MOLLUSCA : PTEROPODA) IN JAPAN ${ }^{1)}$}

SABURo NISHIMURA

Seto Marine Biological Laboratory, Sirahama

With 2 Text-figures

Human dermal afflictions due to stings or penetrations of marine organisms are well documented, but most of the previous records were concerned with the cases in which coelenterates or schistosome cercariae were involved. Reports incriminating organisms other than the above-mentioned animal groups as the causative agent in marine contact dermatitis are rather scarce but they cover a great variety of organisms: the blue-green alga Lyngbya (Arnold 1959; Chu 1959; Grauer 1959), the diatom Fragillaria (Fraser \& Lyell 1963 $)^{2}$, the sponges Tedania and Spheciospongia, both only experimentally (Hutton 1952), the polychaete Hermodice, only experimentally (Hutton 1952), the bryozoan Alcyonidium (Seville 1957, cited by FraSer \& Lyell 1963), zoëa larvae of the porcelain crab Polyonyx (ZINN 1954), etc. Creseis acicula RANG, a thecosomatous planktonic pteropod, is known as another agent organism responsible for a particular type of contact dermatitis in the sea.

A case of "sea stings" due to this pteropod was reported by HutTon (1960) from a bathing place at St. Petersburg, Florida, U. S. A. It occurred on August 14, 1959, and approximately 20 persons were afflicted. He states that his paper appears to be the first one reporting that a pteropod can be incriminated for human "sea stings".

Creseis acicula is quite common in the Japanese waters, too; and it is not infrequent to observe the cod end of a plankton net being packed or penetrated densely by sharply-pointed needle-like shells of this animal, especially when the net is hauled in the Kuroshio or the warm Tsushima current area, and in such cases we feel much difficulty in handling the net. Hitherto, however, only two cases of "sea stings" have ever been reported in Japan in which this pteropod is incriminated definitely as the causative agent, so

1) Contributions from the Seto Marine Biological Laboratory, No. 443.

2) BELL (1961) reports an interesting case that setae of the frustule of a marine diatom Chatoceros sp. have been penetrated into the gill tissue of the lingcod Ophiodon elongatus.

Publ. Seto Mar. Biol. Lab., XIII (4), 287-290, 1965. (Article 15) 
far as I am aware.

Case One

This case was reported by myself in a Japanese journal published nine months earlier than Hutron's report. The following is the digest of my report (NISHIMURA 1960):

On August 6, 1959, several persons swimming in the shallow inshore part of Hiyoriyama bathing place, Niigata, suffered "sea stings" (Text-fig. 1). Mr. Tôgo KAITANI, a teacher of the Niigata Primary School, who was one of the victims, found that numerous minute, trans. parent and needle-like organisms had penetrated his bathing suit and these stung his waist

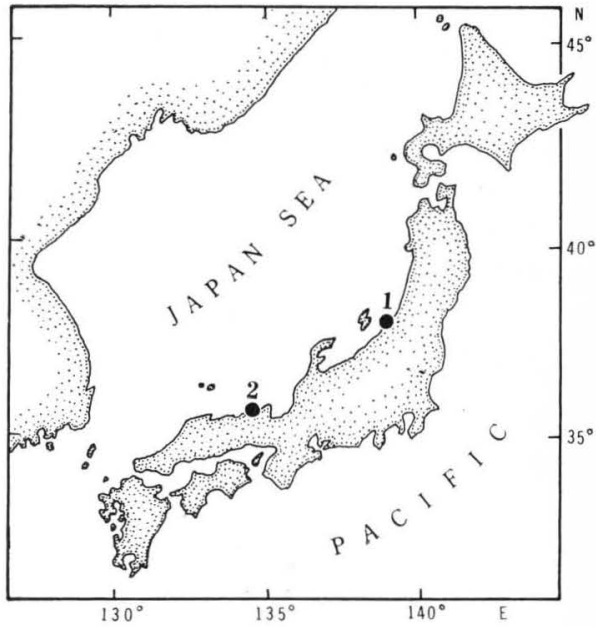

Text-fig. 1. Showing the places where the "sea stings" by Creseis acicula were recorded in Japan. 1.-Niigata; 2.-Coast from Hamasaka to Kasumi.

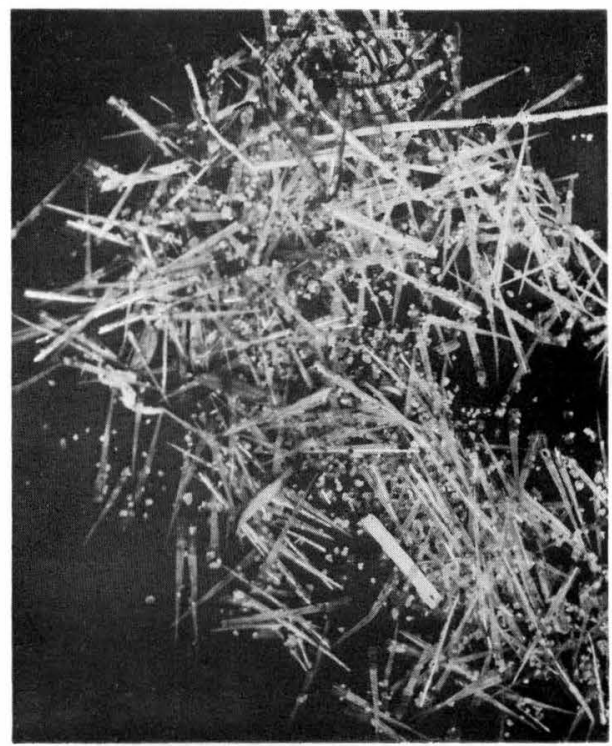

Text-fig. 2. Shells of Creseis acicula stranded on the beach at Hiyoriyama bathing place, Niigata, on August 6, 1959. ×1.2 (Through the courtesy of the Niigata Nippo Newspaper Company, Niigata).

or thigh when they were moved. By careful observation, he ascertained that many living "needles" were swimming in the sea and the same organisms were also stranded on the beach (Text-fig. 2). He brought some specimens to the Public Health Service Department of the Niigata Prefectural Office, and these were finally placed under my disposal, as I was one of the staff of the Japan Sea Regional Fisheries Research Laboratory in Niigata at that time. The organisms were identified with Creseis acicula RANG. They were fairly smaller than the adult size recorded for the species (see TokIokA 1947); the larger shells measured only 11 to $12 \mathrm{~mm}$ in length and nearly $1 \mathrm{~mm}$ in diameter at the aperture. No further prolongation of the initial irritation was complained of by any of the victims.

Subsequent inquiries disclosed that another similar accident had occurred at Yoriihama bathing place near Hiyoriyama on August 2 . 
Case $T w o$

This is the case informed me in his personal communication of May 11, 1965, by Mr. Mototsugu HAMABE of the Coastal Resources Department of the Nankai Regional Fisheries Research Laboratory at Nobeoka, Kyushu, which was made while he was at the Kasumi Branch of the Japan Sea Regional Fisheries Research Laboratory at Kasumi, Hyôgo Prefecture in west Honshu. He mentions as follows:

On August 9 to 10 and subsequent days, 1964, swarms of Creseis acicula drifted to the inshore waters along the coast from Hamasaka to Kasumi, facing the Japan Sea (Text-fig. 1), and no less than 300 swimmers were afflicted. Mr. HAMABE and his daughter happened to experience the stings by themselves while they were bathing in the sea and found that numerous animals were clinging to their bathing suits; they also witnessed many pteropods swimming in the water. Generally, no further continuance of the initial light irritation was appealed, but exceptionally a slight eruption was observed on some persons with high sensitivity. This accident was the first experience even to Mr. HAMABE, who had been a keen observer of marine life in the southern Japan Sea for more than 15 years.

So far as I am aware, no report has been made on the "pteropod stings" from the Pacific side of Japan. Dr. Takasi TokiokA of our laboratory informed me that he had never heard of any mass drift of Creseis to the bathing places at Shimoda of the Izu Peninsula or at Sirahama of the Kii Peninsula. Dr. Yoshitsugu Hirosaki of the Enoshima Aquarium at Enoshima, Kanagawa Prefecture, tells through his personal communication of May 21, 1965, that no such accident has ever been experienced at Enoshima, one of the most famous bathing places on the Pacific side of Japan, though Creseis is occasionally caught in large numbers by fishing nets mingled with the commercial items such as shirasu larvae of clupeoid fishes and in such cases pteropods are accused for lowering the market value of the products.

Before closing this short note, I wish to acknowledge my indebtedness to Messrs. T. Kaitani and M. Hamabe, Drs. T. Tokioka and Y. Hirosaki for their kind informations.

\section{REFERENCES}

ARnold, H. L., Jr. 1959. Sea weed dermatitis apparently caused by a marine alga. Proc. Hawaiian Acad. Sci., 34th Ann. Meeting, 1958-1959.

BELl, G. R. 1961. Penetration of spines from a marine diatom into the gill tissue of lingcod (Ophiodon elongatus). Nature, vol. 192, pp. 279-280.

$\mathrm{C}_{\mathrm{HU}}$, G. W. T. C. 1959. Sea weed dermatitis apparently caused by a marine alga. Proc. Hawaiian Acad. Sci., 34th Ann. Meeting, 1958-1959.

Fraser, J. H. \& Lyell, A. 1963. Dogger Bank itch. The Lancet, Jan. 5, 1963, p. 61.

GRAUER, F. H. 1959. Sea weed dermatitis apparently caused by a marine alga. Proc. Hawaiian Acad. Sci., 34th Ann. Meeting, 1958-1959, 
Hutron, R. F. 1952. Schistosome cercariae as the probable cause of seabather's eruption. Bull. Mar. Sci. Gulf \& Carib., vol. 2, pp. 346-359.

1960. Marine dermatosis. Arch. Derm., vol. 82, pp. 951-956.

NishimurA, S. 1960. Sea-bathers troubled with an emergence of the pricking Creseiid pteropod. Saishu to Shiiku, vol. 22, pp. 74-75. (In Japanese).

TokIoKA, T. 1947. Creseis acicula RANG; Creseis virgula RANG. Ill. Encycl. Fauna Japan (rev. ed.), p. 1079. (In Japanese).

ZINN, D. J. 1954. Pruritus produced by the zooea larvae of one of the porcelain crabs. J. Parasit., vol. 49, pp. 233-234. 